\title{
Tetracycline-resistant bacteria and ribosomal protection protein genes in soils from selected agricultural fields and livestock farms
}

\author{
Kathyleen Nogrado ${ }^{1,5}$, Tatsuya Unno ${ }^{2}$, Hor-Gil Hur ${ }^{3}$ and Ji-Hoon Lee ${ }^{1,4^{*}}$ (D)
}

\begin{abstract}
Antibiotic resistance in soil environment has eminently been compared and studied between agricultural and pristine soils, and the role of concentrated animal feeding operations has markedly been recognized as one of the major sources of antibiotic resistance. This study described the tetracycline resistance in small-scale farms in pursuit of presenting its possible role and contribution to the persistence of antibiotic resistance in the environment. Results of the study would render additional information on the occurrence of the ribosomal protection protein (RPP) tet genes among the isolated bacteria from the selected agricultural soils. Four tetracycline resistance and RPP genes were determined in two different agricultural soil settings. Both the culture and molecular method were used to determine and measure tetracycline resistance in soils from arable land and animal house. Results revealed a significantly higher number of culturable antibiotic-resistant bacteria in animal houses than arable lands which was suggestive of higher antibiotic resistance in areas where there was direct administration of the antibiotics. However, quantification of the gene copy numbers in the agricultural soils indicated a different result. Higher gene copy number of tetO was determined in one animal house (IAH-3), while the two other tet genes tet $\mathrm{Q}$ and tetW were found to be higher in arable lands. Of the total 110 bacterial isolates, tetW gene was frequently detected, while tetO gene was absent in any of the culturable bacterial isolates. Principal component analysis of occurrence and gene copy number of RPP tet genes tetO, tetQ, and tetW also revealed highest abundance of RPP tet genes in the manure and arable soils. Another important highlight of this study was the similarity of the RPP tet genes detected in the isolated bacteria from the agricultural soils to the identified RPP tet genes among pathogenic bacteria. Some of the tetracycline-resistant bacterial isolates were also multidrug resistant as it displayed resistance to tetracycline, erythromycin, and streptomycin using disk diffusion testing.
\end{abstract}

Keywords: RPP-tet genes, Agricultural soil, Antibiotics-resistance

\section{Introduction}

Livestock farming is one of the agricultural sectors identified to have high demand for antibiotics [1]. According to Granados-Chinchilla and Rodriguez [2], antibiotics utilized in livestock farming alone amount to approximately two-thirds of the antibiotics produced worldwide.

\footnotetext{
*Correspondence: jhlee@jbnu.ac.kr

1 Department of Bioenvironmental Chemistry, Jeonbuk National University, 567 Baekje-daero, Deokjin-gu, Jeonju-si, Jeollabuk-do 54896, Republic of Korea

Full list of author information is available at the end of the article
}

In South Korea, more than $50 \%$ of the veterinary antibiotics consumed belong to tetracycline class of antibiotics [3]. As a result, concern on the release of antibiotics and most importantly the proliferation of antibiotic resistance genes and antibiotic resistant bacteria to the environment has been raised. Antimicrobials are considered as emerging contaminants and gaining the spotlight of research at the present time, since they are products of intensive uses of antimicrobials that incite significant threat to the effectivity of currently available antibiotics against pathogenic microorganisms [4-7]. There are 
four known mechanisms of resistance to tetracycline, and a total of 59 described tetracycline resistance gene (tet) determinants $[8,9]$. Ribosomal protection proteins (RPPs), which are second to efflux proteins in terms of the number of tet gene determinants, are tetracycline resistance determinants frequently detected in the environment [10-13] and have a total of 12 gene determinants $[14,15]$. Substantially, RPPs also provide bacteria with additional protection from second generation tetracyclines like minocycline and doxycycline $[8,16]$.

Dispersion of antibiotic resistance is rapidly occurring; thus, its mitigation is urgently needed. One potential solution is to conduct surveillance programs; however, one of the challenges is that surveillance done for antibiotic resistant bacteria and antibiotic resistance in the environment is still scant [17-19]. Determining which antibiotic resistance genes is present and which bacteria carries the genes is very crucial in monitoring and performing risk assessment as well as in planning the imperative measures to attenuate dispersion of antibiotic resistance [20, 21]. Now, the culture-independent methods which are basically gene-based have convincingly offered wider scope of coverage of studying antibiotic resistance in the environment. With molecular tools, insights on the ecology of antibiotic resistance genes in agroecosystems and quantitative data could convey efficiencies of the interventions administered [22, 23]. Quantitative data could also be used to serve as background or baseline data during assessment and evaluation especially in relation to potential human health risks $[18,24]$. To characterize ecology of tetracycline resistance in smallscale farms, the objective of the study was to describe tetracycline resistance in arable lands and animal houses by determining antibiotics-resistant bacteria and RPP tet genes and quantifying the tetracycline resistance genes from the three study areas.

\section{Materials and methods \\ Enumeration of total bacteria and culturable tetracycline-resistant bacteria}

The soil samples were collected from agricultural fields and livestock farms located in Gimje, Iksan, and Jangsu in the fall of 2018. In the 3 study areas, a total of 18 soil samples from 9 animal houses and 9 arable lands were collected. Additionally, 3 representative manure samples were collected as available. Soils from livestock farms were collected at approximately $1 \mathrm{~m}$ from the corral, while soils from arable lands were collected directly from the section where crops were planted. From each site, soils collected from three different spots were binned into a composite sample. The animal houses accommodate approximately less than 50 cattle, while the arable lands are used for cultivating food crops. Additional information on study sites is shown in Additional file 1: Table S1, and the information on the location of the sampling sites is indicated in Additional file 1: Data S1.

The total bacterial level was determined by both culture method and 16S rRNA gene quantification, while total number of tetracycline-resistant bacteria was determined by culture method only. The bacterial cultures were performed by inoculating $100 \mu \mathrm{L}$ of serially diluted $1 \mathrm{~g}$ of soil in 0.1X PBS into lysogeny broth (LB) agar supplemented with or without $10 \mu \mathrm{g} / \mathrm{mL}$ tetracycline (Sigma-Aldrich, USA) by pour plate method. Cycloheximide (Sigma-Aldrich, USA) at $20 \mu \mathrm{g} / \mathrm{mL}$ was also added into the media to control the growth of fungi. After incubation for $48 \mathrm{~h}$ at $28^{\circ} \mathrm{C}$, the number of bacterial colonies per gram of soil (CFU/g of soil) was counted. Isolation of tetracycline-resistant bacteria was followed by spreading $50-\mu \mathrm{L}$ volume of inoculum and incubating the plates at 28 and $35^{\circ} \mathrm{C}$. Bacterial isolates were then culture-purified and tested for cell viability [25].

\section{Quantification of total 16S rRNA gene and RPP tet gene copy number}

DNA extraction from soil was performed using DNeasy ${ }^{\circledR}$ PowerSoil Kit (Qiagen, Hilden, Germany) following the manufacturer's instructions. On the other hand, DNA from bacterial isolate was extracted by boiling lysis with some modification [26]. A loopful of bacterial colony was transferred to a $0.2-\mathrm{mL}$ PCR tube with $100 \mu \mathrm{L}$ of deionized sterile distilled water. The PCR tube was incubated in a thermocycler at $95{ }^{\circ} \mathrm{C}$ for $15 \mathrm{~min}$. After incubation, the suspension was transferred to a sterile $1.5-\mathrm{mL}$ microcentrifuge tube. The lysate was then used for molecular testing.

Detection of RPP tet genes from soil samples was performed following the procedures indicated by Aminov et al. [27, 28] with some modifications. The PCR amplification was performed using the Biometra TProfessional thermocycler with the following conditions: initial denaturation at $94{ }^{\circ} \mathrm{C}$ for $5 \mathrm{~min}$, followed by 25 cycles of denaturation at $94{ }^{\circ} \mathrm{C}$ for $30 \mathrm{~s}$, annealing at the indicated temperature for $30 \mathrm{~s}$, elongation at $72{ }^{\circ} \mathrm{C}$ for $30 \mathrm{~s}$, and then a final elongation at $72{ }^{\circ} \mathrm{C}$ for $7 \mathrm{~min}$. The annealing temperature, primer sequence, and amplicon size are indicated in Additional file 1: Table S2. A second round PCR was carried out using $1 \mu \mathrm{L}$ of the first-round PCR product as a template under the same conditions. The second-round PCR products were analyzed by gel electrophoresis in a $2.5 \%(\mathrm{wt} / \mathrm{vol}$ ) agarose gel containing $0.05 \mathrm{mg} / \mathrm{mL}$ ethidium bromide and visualized using FAS-Digi gel imaging system (Nippon Genetics Europe, Germany). Since there were no positive controls for the four tet genes, all samples with positive results were sent to Genotech (Daejeon, South Korea) for sequencing. 
Sequence analysis was confirmed by comparison with data retrieved from BLAST. The confirmed positive samples detected from soil samples were then also used as control for the screening of RPP tet genes among culturepurified tetracycline-resistant bacterial isolates.

Real-time quantitative PCR was performed to determine the absolute copy numbers of $16 \mathrm{~S}$ rRNA gene, tet $\mathrm{O}$, tet $\mathrm{Q}$, tet $\mathrm{S}$, and tet $\mathrm{W}$ using the CFX-Connect ${ }^{\mathrm{TM}}$ Real-Time PCR Detection System (Bio-Rad Laboratories Inc, USA). Standard quantification curves were separately established for the 16S rRNA gene and RPP tet genes following the procedures indicated by Nogrado et al. [29], and absolute gene copy numbers were calculated directly from the extracted plasmids [30]. The qPCR conditions for the four tet genes were programmed according to the conditions used by Wu et al. [10] with some modifications: initial denaturation at $95{ }^{\circ} \mathrm{C}$ for $1 \mathrm{~min}$, followed by 40 cycles of denaturation at $94^{\circ} \mathrm{C}$ for $10 \mathrm{~s}$ and annealing at $58.2{ }^{\circ} \mathrm{C}$ for tet $\mathrm{O}$ and $\operatorname{tet} \mathrm{Q}$, and at $63.3{ }^{\circ} \mathrm{C}$ for tet $\mathrm{W}$ for $45 \mathrm{~s}$. Furthermore, the fluorescence was read at different temperatures, $81^{\circ} \mathrm{C}$ for tet $\mathrm{O}$ and tet $\mathrm{Q}$, and $83^{\circ} \mathrm{C}$ for tetW. Product specificity was confirmed by both melt curve analysis (for $16 \mathrm{~S}$ rRNA gene at $65-95{ }^{\circ} \mathrm{C}$ with an increment of $0.5^{\circ} \mathrm{C}$ held for $30 \mathrm{~s}$ and for the tet genes at $55-95^{\circ} \mathrm{C}$ with an increment of $0.5{ }^{\circ} \mathrm{C}$ held for $30 \mathrm{~s}$ ) and if needed, gel electrophoresis.

\section{Susceptibility testing and identification of tetracycline-resistant bacterial isolates}

The tetracycline-resistant bacterial isolates were identified by analyzing $16 \mathrm{~S}$ rRNA genes amplified using the $27 \mathrm{~F}$ and $1492 \mathrm{R}$ primer set. The PCR products were then purified and sent for sequencing to Genotech (Daejeon, South Korea). Sequence confirmation was done by comparison with data retrieved from BLAST. The antibiotic susceptibility by disk diffusion was performed following the procedures indicated by Ortez [31].

\section{Data analysis}

One-way analysis of variance (ANOVA) was performed to assess the homogeneity of variance among the average of the total culturable bacteria, total culturable tetracycline-resistant bacteria, and total bacterial level by $16 \mathrm{~S}$ rRNA gene copy in two agricultural areas with a $95 \%$ confidence interval. While standard deviation on absolute copy number of RPP tet gene in each site was determined. Using the DNA sequences of the amplified RPP tet genes from the total extracted DNA from soil samples, a neighbor-joining tree was constructed using the MEGA-7 to determine the maximum likelihood of the tet genes detected in the two agricultural settings. Principal component analysis (PCA) was also performed using $\mathrm{R}$ to analyze the distribution and absolute tet gene copy number per gram of soil in each collection site.

\section{Results and discussion}

\section{Total and tetracycline-resistant bacteria}

Using ANOVA with 95\% confidence interval, Fig. 1 shows a statistically significant higher bacterial level in arable land than animal houses using both culture and molecular methods. On the other hand, density of the culturable tetracycline-resistant bacteria was higher in the animal houses $\left(3.13 \times 10^{4} \pm 5.20 \times 10^{3} \mathrm{CFU} / \mathrm{g}\right)$ than in the arable lands $\left(2.89 \times 10^{4} \pm 5.43 \times 10^{3} \mathrm{CFU} / \mathrm{g}\right)$. The higher bacterial level in arable land could be influenced by the tillage activities that affect the soil texture and soil moisture content which influence the soil bacterial abundance [32]. Comparison of percentages of the culturable tetracycline-resistant bacteria in each agricultural site per study area revealed consistently higher ratio in animal house than in arable land (Additional file 1: Table S3). The concentration of tetracycline used for culturing the tetracycline-resistant bacteria in this study followed the methods used by Popowska et al. [33]. The percentage of the total culturable tetracycline-resistant bacteria obtained in this study was higher compared to the results obtained by Kim et al. [13]. This could be attributed to the lower concentration of tetracycline used in this study at 10 $\mu \mathrm{g} / \mathrm{L}$. A lower concentration than the minimum inhibitory concentration was used since in reality, microbes in the environment are exposed to a much lower concentration and that lower antibiotic concentration also enriches resistant microorganisms in the actual environment [34]. In addition to this, although the concentration of tetracycline used is lower than the breakpoint for tetracycline resistance, resistance is dictated more by the cost of fitness exhibited by the microorganism than by the concentration of the antibiotics [35].

\section{Tetracycline-resistant genes}

Looking at the prevalence of four RPP tet genes in the agricultural soils, the results of conventional PCR revealed that the most frequently detected RPP tet gene was tet $\mathrm{W}$ followed by tet $\mathrm{Q}$ and tet $\mathrm{S}$, while the least detected was tet $\mathrm{O}$ which was present in only two sites (Additional file 1: Table S4). Manure samples, on the other hand, showed that all three manure samples indicated the presence of $\operatorname{tet} \mathrm{O}$, tet $\mathrm{Q}$, and tet $\mathrm{W}$ except the Gimje manure sample which was positive only for tet W. There was no positive control for the RPP tet genes detected, and so the PCR products were sent for DNA sequencing for confirmation. After confirmation, a phylogenetic tree was constructed by neighbor-joining method (Fig. 2). The figure shows a high similarity of RPP tet genes detected in the two agricultural soil 


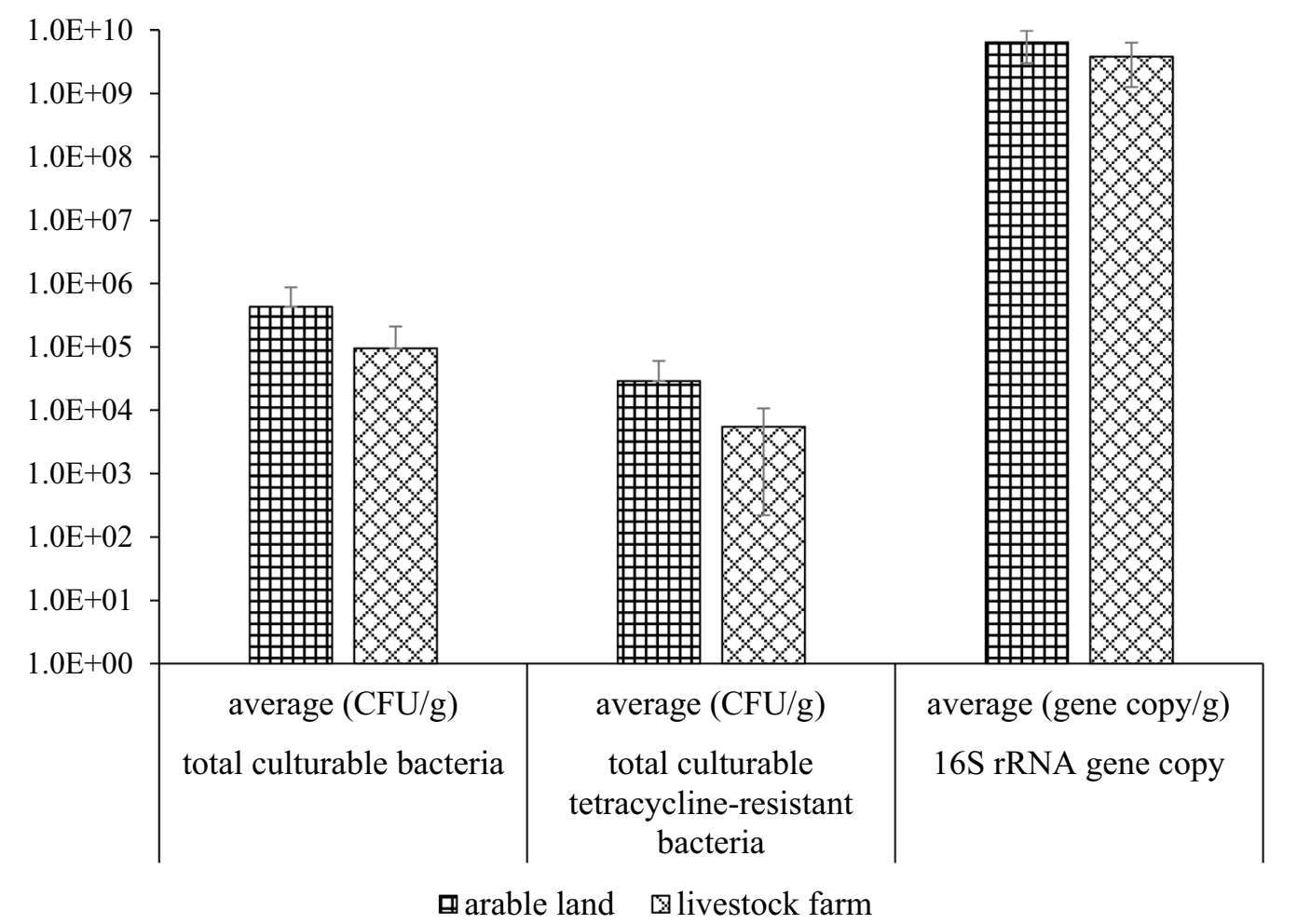

Fig. 1 Comparison of the average of total culturable bacterial level by culture and molecular method and total culturable tetracycline-resistant bacteria in arable land and animal house. ANOVA was used to determine the significance of difference in the average values of total culturable bacterial level and total culturable tetracycline-resistant bacteria in the two areas at 95\% confidence interval

environments, and most notably these RPP tet genes bear resemblance to previously identified RPP tet genes among pathogenic microorganisms. The abundance of the RPP tet genes was then determined by quantitative real-time PCR and was reported as ratio (or relative gene copy number) between tet gene copy and total 16S rRNA gene copy per gram of soil (Fig. 3). Among the three genes quantified, tet $\mathrm{W}$ was found to have the highest relative gene copy number than the other two tet genes. The tet $\mathrm{W}$ ratio was found to be highest in JAF-2 and GAH-2 sites with $1.84 \times 10^{-4} \pm 4.32 \times 10^{-5}$ and $1.42 \times 10^{-4} \pm 5.64 \times 10^{-5}$, respectively. Subsequently, tet $\mathrm{W}$ was followed by the gene copy number of tet $\mathrm{O}$ which was higher in IAH-3 at $1.64 \times 10^{-5} \pm 5.07 \times 10^{-6}$ than in GAF-1 at $3.65 \times 10^{-6} \pm 9.87 \times 10^{-7}$. Lastly, the relative copy number of tet $\mathrm{Q}$ was found to be higher in GAF-1 $\left(6.26 \times 10^{-6} \pm 8.46 \times 10^{-6}\right)$ compared to that in IAH-1 $\left(2.39 \times 10^{-6} \pm 1.12 \times 10^{-6}\right)$. The results demonstrated that tet $\mathrm{W}$ and tet $\mathrm{Q}$ were more abundant in arable land, while tet $\mathrm{O}$ was more in livestock farms. The abundance of the RPP tet genes in manure samples followed the same pattern to that of the soil samples. Additionally, among manure samples, manure from Jangsu had the highest relative gene copy number of the tet genes compared to Gimje and Iksan (Fig. 3). Figure 4 shows the principal component analysis (PCA) of the gene abundance in each site showing clustering of sites in terms of the abundance and presence of the RPP tet genes. It revealed that tet genes were the most abundant in the following samples J-manure>I-compost>GAF-1. The figure also shows that tet $\mathrm{O}$ and tet $\mathrm{W}$ were strongly correlated to each other, which could be explained by its high similarity of amino acid sequences between TetO and TetW, which were categorized into the same group based on the amino acid sequence similarity [8]. The results of this study in terms of the frequency of detection of the RPP tet genes showed that tet $\mathrm{O}$ and tetQ, were not as prevalent in the agricultural sites evaluated compared to previous agricultural sites evaluated in previous studies $[10,13,36]$. The widespread detection of tet $\mathrm{W}$ in both arable land and livestock farms was in agreement with other studies [11, 13,36], while the infrequent detection of tet $\mathrm{S}$ in the agricultural areas of study coincided with the results obtained by Wu et al. [10]. It is important to note that one animal house in Iksan was found to be negative for the presence of any RPP tet genes. This is possibly not truly negative as this could be attributed to PCR inhibitors present in the soil samples from this area [11]. 


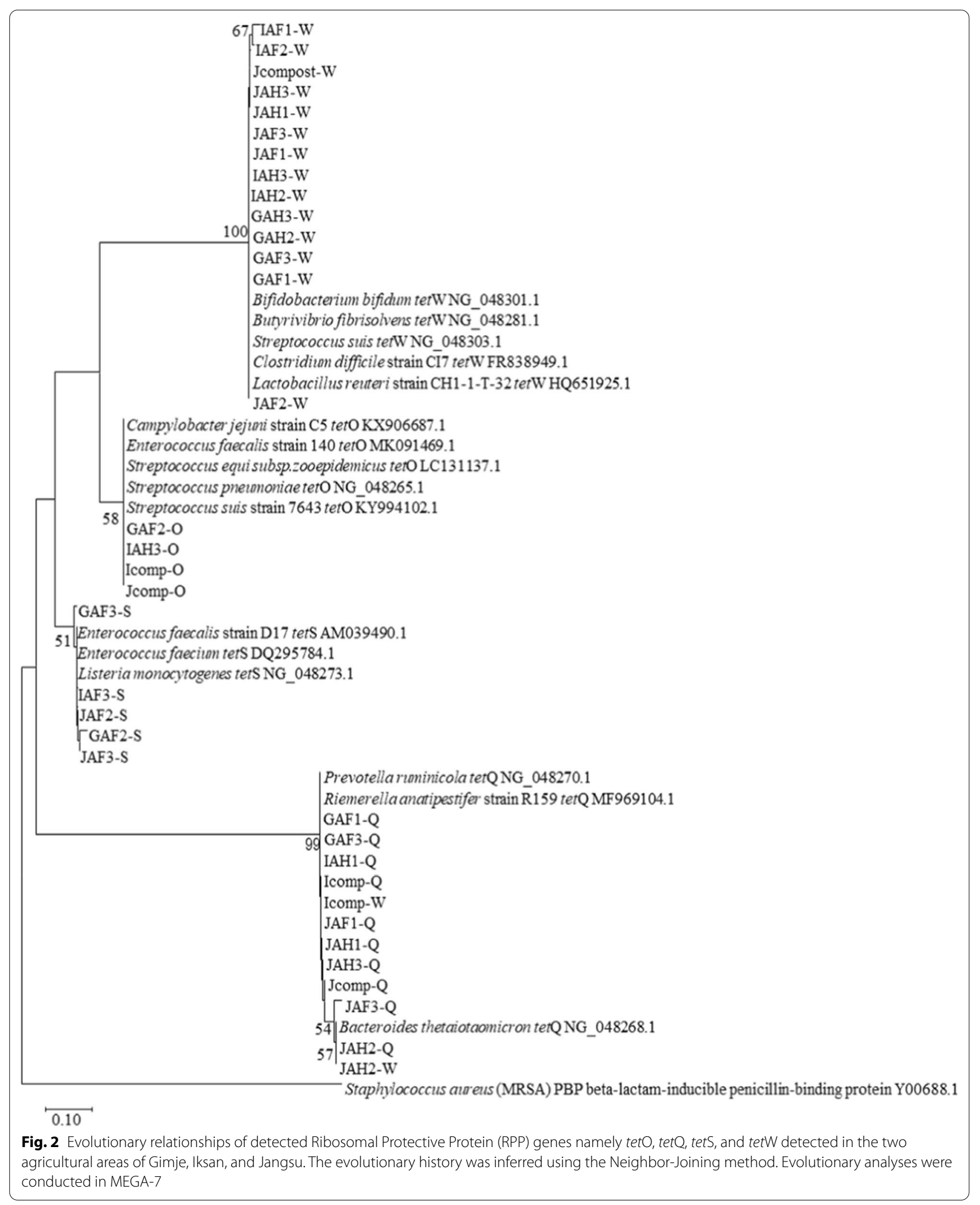



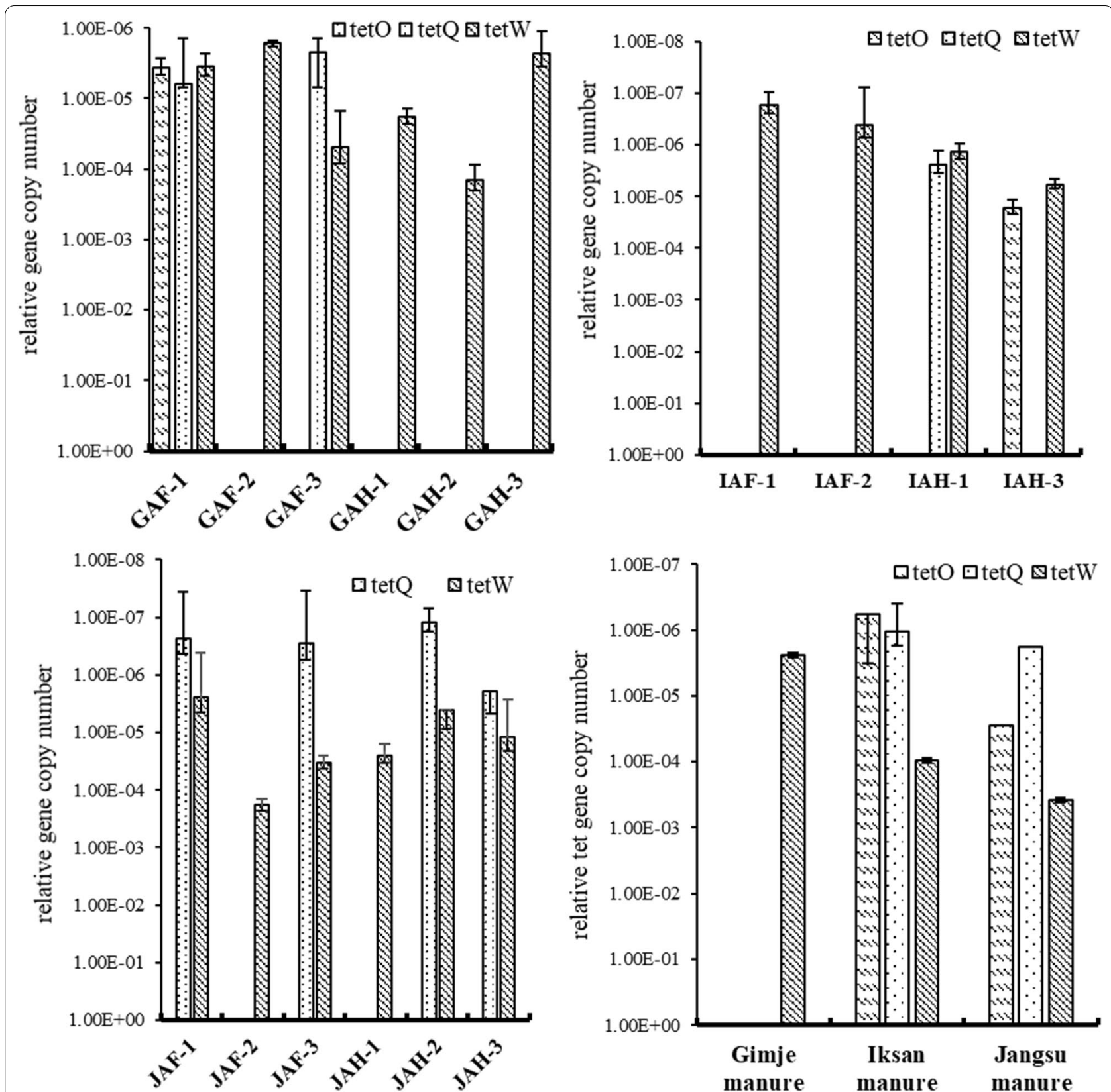

Fig. 3 Relative copy number of tet genes to the $16 \mathrm{~S}$ rRNA gene in soil and compost samples collected from arable land and livestock farm in Gimje, Iksan, and Jangsu

One of the contributing factors to the enrichment of antibiotic resistance genes in the environment is the application of manure as fertilizer [37]. In this study, manure samples were only collected when available. Now, among the three manure samples, Gimje manure sample showed to have tet $\mathrm{W}$ only. This could be explained by the difference in the crudity of the three manure samples, showing that Gimje manure has already undergone composting. The effect of composting on the reduction of antibiotic resistance genes has been observed in the study by Wang et al. [38]. While antibiotic genes are acknowledged to be naturally present in the environment, mere determination of its frequency can give incomplete details whether it could be considered as background level or baseline level, and so quantification of the gene copy number was also performed to assess the magnitude of the occurrence of the RPP tet genes [13, 23]. Quantification of the RPP tet genes can be used to determine if it could be used as a 


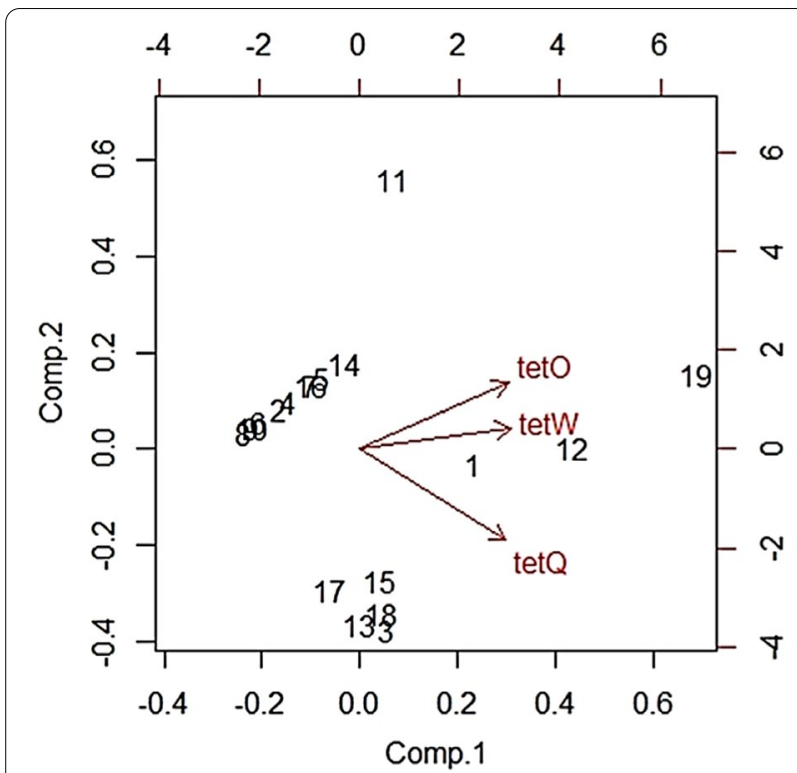

Fig. 4 PCA biplot clustering based on antibiotic resistance abundance. Each number represents an individual sample tested in this study and clustered according to the abundance of three tetracycline resistance genes. (\# 1-3: GAF-1 to GAF-3; \# 4-6: GAH-1 to GAH-3; \# : Gimje-manure; \# 8, 9: IAF-1 and IAF-2; \# 10, 11: IAH-1 and IAH-3; \# 12: Iksan-manure; \# 13-15: JAF-1 to JAF-3; \# 16-18: JAH-1 to JAH-3; and \# 19: Jangsu-manure)

background or baseline level which is important to confirm the causes of antibiotic resistance in agro-ecosystems, to evaluate the change or variation of the antibiotic resistance level over time, and to establish relationship of the use of antibiotics in agriculture and spread of resistance [18]. It is also essential to determine myriad of antibiotic resistance genes that occur in the environment as this will aid which antibiotic resistance genes should be included for monitoring during surveillance [15]. Likewise, quantification of the antibiotic resistance genes could also be used to check the efficiency of the intervention applied to reduce antibiotic resistance [24].

\section{Tetracycline-resistant isolates and the genes}

A total of 110 bacterial isolates were subjected for antibiotic susceptibility using disk diffusion assay (Additional file 1: Data S2); however, the test was applicable only to 77 isolates as some did not grow well in Mueller Hinton Agar (MHA). Out of the 77 bacterial isolates, 69 isolates were tetracycline-resistant except for 8 bacterial isolates. However, these 8 bacterial isolates were found to be resistant to either erythromycin or streptomycin. Multidrug resistance was also observed in the following genera in each site: from Gimje, Citrobacter, Bhargavaea, and bacterial isolates classified as Proteobacteria; from Iksan, Chryseobacterium, Paenibacillus, Streptomyces, and Bacillus; from Jangsu,
Serratia, Streptomyces, Burkholderia, and one classified under family Yersiniaceae. It is important to note that some of these genera have species that are considered pathogens. The conventional PCR among the bacterial isolates revealed that 57 isolates among 110 tested were negative for the presence of any of the four RPP tet genes, while the remaining 53 bacterial isolates were positive for the presence of RPP tet gene. The most frequently detected RPP tet gene was tet $\mathrm{W}$ which was present in 37/53 isolates. On the other hand, 11/53 isolates were found positive for tet $\mathrm{Q}$, and 23/53 isolates were found positive for tet $\mathrm{S}$. Furthermore, 14/53 isolates carried two RPP tet genes and 2/53 isolates had three tet genes namely tet $\mathrm{Q}$, tet $\mathrm{S}$, and tet $\mathrm{W}$. The tet $\mathrm{O}$ was not detected in any of the 53 bacterial isolates. This could imply the possibility of its presence among nonculturable or difficult-to-culture bacteria, since the tet $\mathrm{O}$ gene was detected in the total extracted DNA from Gimje and Iksan soil samples. Another possibility is that majority of the tet $\mathrm{O}$ in the study area resides in the chromosome of resident bacteria resulting to its limitation to be transferred to other bacterial host [39]. This is in contrast to tet $\mathrm{W}$, which is the frequently detected RPP tet gene and which has the highest tet gene relative copy number. This could be explained by its association with conjugative transposons [40]; however, further studies should be done to substantiate this presumption. Lastly, antibiotic susceptibility testing results revealed that some of the bacterial isolates were multidrug-resistant to commonly used antibiotics in agriculture. Identification of the bacterial isolates exhibiting the multidrug resistance is important in assessing the risk to human health since multidrug resistance is considered a public health crisis. Furthermore, identification of the bacterial isolates could also hint the possible source that is crucial to understanding the ecology of antibiotic resistance, which in turn help in creating measures to hinder or prevent its rapid transmission. High prevalence and high quantified gene copy number of antibiotic resistance gene is indicative of its inclusion for surveillance [41-43].

\section{Supplementary Information}

The online version contains supplementary material available at https://doi. org/10.1186/s13765-021-00613-6.

Additional file 1: Table S1. Soil samples collected from arable land and livestock farms located in Gimje, Iksan, and Jangsu. Table S2. List of PCR primers used to amplify selected Ribosomal Protection Proteins (RPP) tet genes and 165 rRNA gene using both conventional and real-time PCR (qPCR). Table S3. Percent of total culturable tetracycline-resistant (CFU/g) to total culturable bacteria (CFU/g) in soils collected from arable land and livestock farms in three study areas. Table S4. Prevalence of RPP tet gene in different agricultural sites in three study areas. Data S1. GPS data of soil sample collection sites. Data S2. Summary of KB testing to three antibiotics and molecular testing of tetO, tetQ, tetS, and tetW of bacterial isolates from the three study areas. 


\section{Acknowledgements \\ Not applicable}

\section{Authors' contributions}

KN performed and analyzed the soil antibiotics-resistant bacteria as the main contributor of the writing. TU and $\mathrm{H}-\mathrm{GH}$ suggested constructive ideas and revised the manuscript. J-HL designed and supervised this research. All authors read and approved the final manuscript.

\section{Funding}

This study was funded by the Cooperative Research Programs for Agricultural Science and Technology Development (Project No. PJ014852, PJ015716032021), Rural Development Administration, Republic of Korea.

\section{Availability of data and materials}

Supplementary Material is followed.

\section{Declarations}

\section{Competing interests}

Not applicable.

\section{Author details}

'Department of Bioenvironmental Chemistry, Jeonbuk National University, 567 Baekje-daero, Deokjin-gu, Jeonju-si, Jeollabuk-do 54896, Republic of Korea. ${ }^{2}$ Faculty of Biotechnology, Jeju National University, Jeju 63243, Republic of Korea. ${ }^{3}$ School of Environmental and Earth Science, Gwangju Institute of Science and Technology, Gwangju 61005, Republic of Korea. ${ }^{4}$ Department of Agricultural Convergence Technology, Jeonbuk National University, Jeonju 54896, Republic of Korea. ${ }^{5}$ Present Address: Department of Molecular Tropical Medicine and Genetics, Mahidol University, Bangkok 10400, Thailand.

\section{Received: 7 April 2021 Accepted: 12 May 2021}

\section{Published online: 18 May 2021}

\section{References}

1. Kim B, Ji K, Kim C, Kang H, Lee S, Kwon B, Kho Y, Park K, Kim K, Choi K (2019) Pharmaceutical residues in streams near concentrated animal feeding operations of Korea-occurrences and associated ecological risks. Sci Total Environ 655:408-413. https://doi.org/10.1016/j.scitotenv. 2018.11.233

2. Granados-Chinchilla F, Rodriguez C (2017) Tetracyclines in food and feedingstuffs: From regulation to analytical methods, bacterial resistance, and environmental and health implications. J Anal Methods Chem 2017:1-24. https://doi.org/10.1155/2017/1315497

3. Tasho RP, Cho JY (2016) Veterinary antibiotics in animal waste, its distribution in soil and uptake by plants: a review. Sci Total Environ 563-564:366376. https://doi.org/10.1016/j.scitotenv.2016.04.140

4. Heuer $H$, Schmitt $H$, Smalla K (2011) Antibiotic resistance gene spread due to manure application on agricultural fields. Curr Opin Microbiol 14(3):236-243. https://doi.org/10.1016/j.mib.2011.04.009

5. DeVries SL, Zhang P (2016) Antibiotics and the terrestrial nitrogen cycle: a review. Curr Pollut Rep 2(1):51-67. https://doi.org/10.1007/ s40726-016-0027-3

6. Aslam B, Wang W, Arshad MI, Khurshid M, Muzammil S, Rasool MH, Nisar MA, Alvi RF, Aslam MA, Qamar MU, Salamat MKF, Baloch Z (2018) Antibiotic resistance: a rundown of a global crisis. Infect Drug Resist 11:1645-1658. https://doi.org/10.2147/IDR.S173867

7. Cycoń M, Mrozik A, Piotrowska-Seget Z (2019) Antibiotics in the soil environment-degradation and their impact on microbial activity and diversity. Front Microbiol 10:338. https://doi.org/10.3389/fmicb.2019. 00338

8. Chopra I, Roberts M (2001) Tetracycline antibiotics: mode of action, applications, molecular biology, and epidemiology of bacterial resistance Microbiol Mol Biol Rev 65(2):232-260. https://doi.org/10.1128/MMBR. 65.2.232-260.2001

9. Marosevic D, Kaevska M, Jaglic Z (2017) Resistance to the tetracyclines and macrolide-lincosamide-streptogramin group of antibiotics and its genetic linkage_a review. Ann Agric Environ Med 24:338-344. https:// doi.org/10.26444/aaem/74718

10. Wu N, Qiao M, Zhang B, Cheng W-D, Zhu Y-G (2010) Abundance and diversity of tetracycline resistance genes in soils adjacent to representative swine feedlots in China. Environ Sci Technol 44(18):6933-6939. https://doi.org/10.1021/es1007802

11. Yang $H$, Byelashov OA, Geornaras I, Goodridge LD, Nightingale KK, Belk KE, Smith GC, Sofos JN (2010) Presence of antibiotic-resistant commensal bacteria in samples from agricultural, city, and national park environments evaluated by standard culture and real-time PCR methods. Can J Microbiol 56(9):761-770. https://doi.org/10.1139/w10-060\%m20921986

12. Kobashi Y, Hasebe A, Nishio M, Uchiyama H (2007) Diversity of tetracycline resistance genes in bacteria isolated from various agricultural environments. Microbes Environ 22:44-51

13. Kim SY, Kuppusamy S, Kim JH, Yoon Y-E, Kim K-R, Lee YB (2016) Occurrence and diversity of tetracycline resistance genes in the agricultural soils of South Korea. Environ Sci Pollut Res Int 23(21):22190-22196. https://doi.org/10.1007/s11356-016-7574-4

14. Grossman TH (2016) Tetracycline antibiotics and resistance. Cold Spring Harb Perspect Med 6(4):a025387-a025387. https://doi.org/10.1101/cshpe rspect.a025387

15. Roberts MC, Schwarz S (2016) Tetracycline and phenicol resistance genes and mechanisms: Importance for agriculture, the environment, and humans. J Environ Qual 45(2):576-592. https://doi.org/10.2134/jeq2015. 04.0207

16. Nguyen F, Starosta A, Arenz S, Sohmen D, Dönhöfer A, Wilson D (2014) Tetracycline antibiotics and resistance mechanisms. Biol Chem. https:// doi.org/10.1515/hsz-2013-0292

17. Thanner S, Drissner D, Walsh F (2016) Antimicrobial resistance in agriculture. MBio 7(2):e02227-e12215. https://doi.org/10.1128/mBio.02227-15

18. Iwu CD, Korsten L, Okoh Al (2020) The incidence of antibiotic resistance within and beyond the agricultural ecosystem: a concern for public health. MicrobiologyOpen 9(9):e1035. https://doi.org/10.1002/mbo3. 1035

19. Huijbers PMC, Flach C-F, Larsson DGJ (2019) A conceptual framework for the environmental surveillance of antibiotics and antibiotic resistance. Environ Int 130:104880. https://doi.org/10.1016/j.envint.2019.05.074

20. Sanderson H, Fricker C, Brown RS, Majury A, Liss S (2016) Antibiotic resistance genes as an emerging environmental contaminant. Environ Rev. https://doi.org/10.1139/er-2015-0069

21. World Health O, Food, Agriculture Organization of the United N, World Organisation for Animal $\mathrm{H}$ (2019) Monitoring and evaluation of the global action plan on antimicrobial resistance: framework and recommended indicators. World Health Organization, Geneva

22. Rothrock MJ Jr, Keen PL, Cook KL, Durso LM, Franklin AM, Dungan RS (2016) How should we be determining background and baseline antibiotic resistance levels in agroecosystem research? J Environ Qual 45(2):420-431. https://doi.org/10.2134/jeq2015.06.0327

23. Cadena M, Durso LM, Miller DN, Waldrip HM, Castleberry BL, Drijber RA, Wortmann C (2018) Tetracycline and sulfonamide antibiotic resistance genes in soils from nebraska organic farming operations. Front Microbiol 9:1283-1283. https://doi.org/10.3389/fmicb.2018.01283

24. Ishii S (2020) Quantification of antibiotic resistance genes for environmental monitoring: current methods and future directions. Curr Opin Environ Sci Health 16:47-53. https://doi.org/10.1016/j.coesh.2020.02.004

25. Kobashi Y, Hasebe A, Nishio M (2005) Antibiotic-resistant bacteria from feces of livestock, farmyard manure, and farmland in japan-case report-. Microbes Environ 20(1):53-60. https://doi.org/10.1264/jsme2.20.53

26. Schmitt M, Pawlita M (2009) High-throughput detection and multiplex identification of cell contaminations. Nucleic Acids Res 37(18):e119-e119. https://doi.org/10.1093/nar/gkp581

27. Aminov RI, Chee-Sanford JC, Garrigues N, Teferedegne B, Krapac IJ, White BA, Mackie RI (2002) Development, validation, and application of pcr primers for detection of tetracycline efflux genes of Gram-negative bacteria. Appl Environ Microbiol 68(4):1786-1793. https://doi.org/10.1128/ aem.68.4.1786-1793.2002

28. Aminov RI, Garrigues-Jeanjean N, Mackie RI (2001) Molecular ecology of tetracycline resistance: development and validation of primers for detection of tetracycline resistance genes encoding ribosomal protection 
proteins. Appl Environ Microbiol 67(1):22-32. https://doi.org/10.1128/ aem.67.1.22-32.2001

29. Nogrado K, Lee S, Chon K, Lee J-H (2019) Effect of transient exposure to carbaryl wettable powder on the gut microbial community of honey bees. Appl Biol Chem 62(1):6. https://doi.org/10.1186/s13765-019-0415-7

30. Ritalahti KM, Amos BK, Sung Y, Wu Q, Koenigsberg SS, Löffler FE (2006) Quantitative PCR targeting 16S rRNA and reductive dehalogenase genes simultaneously monitors multiple Dehalococcoides strains. Appl Environ Microbiol 72(4):2765-2774. https://doi.org/10.1128/aem.72.4.2765-2774. 2006

31. Ortez JH (2005) Disk diffusion testing. In: Coyle MB (ed) Manual of antimicrobial susceptibility testing. American Society for Microbiology, Washington, DC

32. Wang Z, Liu L, Chen Q, Wen X, Liao Y (2016) Conservation tillage increases soil bacterial diversity in the dryland of northern China. Agron Sustain Dev 36(2):28. https://doi.org/10.1007/s13593-016-0366-x

33. Popowska M, Rzeczycka M, Miernik A, Krawczyk-Balska A, Walsh F, Duffy B (2012) Influence of soil use on prevalence of tetracycline, streptomycin, and erythromycin resistance and associated resistance genes. Antimicrob Agents Chemother 56(3):1434-1443. https://doi.org/10.1128/aac. 05766-11

34. Sandegren $L$ (2014) Selection of antibiotic resistance at very low antibiotic concentrations. Upsala J Med Sci 119(2):103-107. https://doi.org/10 3109/03009734.2014.904457

35. Guo B, Abdelraouf K, Ledesma K, Nikolaou M, Tam V (2012) Predicting bacterial fitness cost associated with drug resistance. J Antimicrob Chemother 67(4):928-932

36. Li C, Jiang C, Wu Z, Cheng B, An X, Wang H, Sun Y, Huang M, Chen X, Wang J (2018) Diversity of antibiotic resistance genes and encoding ribosomal protection proteins gene in livestock waste polluted environment. J Environ Sci Health B 53:1-11. https://doi.org/10.1080/03601234.2018. 1438836

37. Scott A, Tien Y-C, Drury CF, Reynolds WD, Topp E (2018) Enrichment of antibiotic resistance genes in soil receiving composts derived from swine manure, yard wastes, or food wastes, and evidence for multiyear persistence of swine Clostridium spp. Can J Microbiol 64(3):201-208. https://doi. org/10.1139/cjm-2017-0642

38. Wang C, Dong D, Strong PJ, Zhu W, Ma Z, Qin Y, Wu W (2017) Microbial phylogeny determines transcriptional response of resistome to dynamic composting processes. Microbiome 5(1):103. https://doi.org/10.1186/ s40168-017-0324-0

39. Roberts MC (1996) Tetracycline resistance determinants: mechanisms of action, regulation of expression, genetic mobility, and distribution. FEMS Microbiol Rev 19(1):1-24. https://doi.org/10.1111/j.1574-6976.1996.tb002 51.x

40. Roberts MC (2005) Update on acquired tetracycline resistance genes. FEMS Microbiol Lett 245(2):195-203. https://doi.org/10.1016/j.femsle. 2005.02.034

41. Berendonk TU, Manaia CM, Merlin C, Fatta-Kassinos D, Cytryn E, Walsh F, Bürgmann H, Sørum H, Norström M, Pons M-N, Kreuzinger N, Huovinen P, Stefani S, Schwartz T, Kisand V, Baquero F, Martinez JL (2015) Tackling antibiotic resistance: the environmental framework. Nat Rev Microbiol 13(5):310-317. https://doi.org/10.1038/nrmicro3439

42. Manaia CM (2017) Assessing the risk of antibiotic resistance transmission from the environment to humans: non-direct proportionality between abundance and risk. Trends Microbiol 25(3):173-181. https://doi.org/10. 1016/j.tim.2016.11.014

43. Shin SW, Shin MK, Jung M, Belaynehe KM, Yoo HS (2015) Prevalence of antimicrobial resistance and transfer of tetracycline resistance genes in Escherichia coli isolates from beef cattle. Appl Environ Microbiol 81(16):5560-5566. https://doi.org/10.1128/aem.01511-15

\section{Publisher's Note}

Springer Nature remains neutral with regard to jurisdictional claims in published maps and institutional affiliations.

\section{Submit your manuscript to a SpringerOpen ${ }^{\odot}$ journal and benefit from:}

- Convenient online submission

- Rigorous peer review

- Open access: articles freely available online

- High visibility within the field

- Retaining the copyright to your article

Submit your next manuscript at $\boldsymbol{\nabla}$ springeropen.com 